\title{
The search for the ideal influenza vaccine
}

\author{
FRED M. DAVENPORT \\ M.D. \\ School of Public Health, The University of Michigan Department of Epidemiology, \\ Ann Arbor, Michigan 48109, U.S.A.
}

\begin{abstract}
Summary
The history of the development of influenza virus vaccine is traced from its origin with experimental studies of influenza virus in ferrets and mice and the first trials in man. Knowledge of the basis of immunity to the viruses in experimental animals and in man has grown steadily over the years and has been essential to successful immunization. Virus variation affecting the surface antigens of the virus is seen as the principal obstacle to the application of vaccines in man. So significant are the changes occurring during antigenic drift that former concepts of a polyvalent vaccine cannot provide a solution of the problem of the composition of vaccines. Disrupted virus vaccines appear to provide the answer to the prevention of vaccine reactions.
\end{abstract}

EFFORTS to develop an ideal influenza vaccine stem basically from studies carried out at Mill Hill more than 4 decades ago. Smith, Andrewes and Laidlaw (1933) initiated the quest in 1933 by isolating, identifying, and characterizing one of the causal agents of epidemic influenza. Convalescent ferrets were found to be immune to challenge and their sera as well as those of recovered patients exhibited neutralizing activity. Clearly the virus could be contained.

In 1934, Andrewes, Laidlaw and Smith (1934) described adaptation of swine and human influenza viruses to mice. Prevention of lung lesions by use of hyperimmune horse serum authenticated their specificity. Rodents given adapted virus subcutaneously did not become infected and seemed to develop partial immunity. More detailed accounts appeared in 1935. Laidlaw et al. (1935) reported that hyperimmune horse serum or its pseudo-globulin fraction conferred some degree of passive immunity when given to mice, before or even after challenge. In a companion paper, Smith, Andrewes and Laidlaw (1935) demonstrated that ferrets developed neutralizing serum antibodies after subcutaneous injection of live or formalin-inactivated virus suspensions. Nevertheless, by clinical criteria, these animals were fully susceptible when given virus intranasally without benefit of anaesthesia. Now Shope had written that prior administration of live virus subcutaneously prevented the pneumonia which develops after intranasal administration of swine virus to anaesthetized ferrets. Further, he had earlier published that intramuscular injection of active swine virus conferred firm immunity to pigs challenged via the respiratory route (Shope, 1932). Smith et al. (1935) found it 'inconceivable that possession of neutralizing antibodies in the circulation should confer no sort of benefit'. They extended Shope's vaccine experiments in anaesthetized ferrets, using active and formalin-treated suspensions of swine and human strains. In every case vaccination resulted in a partial immunity sufficient to protect the lung from virus attack. Moreover, it was demonstrated that the waning immunity of ferrets held 7-10 months after primary infection could be reinforced to solid immunity by a single subcutaneous dose. Demonstration of partial protection of mice given repeated subcutaneous or intradermal injections of active virus, and further information on the antigenic relationships and differences between swine and human influenza strains were additional components of this remarkably informative paper.

Several portions of the discussion in the paper by Smith et al. (1935) are worth quoting in full. 'In the case of influenza, an attack of the disease confers an immunity which quickly wanes. It is probable, therefore, that any method of active immunization would require to be repeated at intervals in order to maintain a condition of complete resistance'.

'The human population in inter-epidemic periods probably consists for the most part of individuals resembling the recovered ferret with waning immunity rather than the normally fully susceptible animal. Individuals, that is, with a basic immunity represented by virus-neutralizing antibodies in the circulation. The fact that the basic immunity of the ferret can be reinforced to a degree which renders the animal non-susceptible to experimental infection gives hope that similar procedures applied to man at the right time may play a crucial part in the control of an epidemic'.

'Although the two human strains used in this work seem to be immunologically identical, the difference between them and the swine virus would 
lead us to suspect that similar differences may be found among human strains isolated in the future. Should this prove to be the case, the problem of immunization will become correspondingly more difficult'.

Independent contemporary studies carried out by Frances (1934a, b; 1935) and by. Francis and Magill (1935a) gave prompt verification concerning adaptation of virus to mice, protection by vaccination with suspensions of infected lungs, and the serological distinctiveness of swine and human strains.

Since at that time, strains of human influenza virus isolated in London in 3 successive years (Andrewes, Laidlaw and Smith, 1935) and in New York in 2 (Francis and Magill, 1935a) seemed to be immunologically identical, an optimistic outlook for development of a stable influenza vaccine might have been expected. However, Laidlaw (1935) in his 1935 Linacre Lecture expanded on the earlier expressed caveat: 'If there is only one influenza virus, it will not be easy to account for the periodic appearance of the great pandemics which have, from time to time, spread over the world. There are probably several factors concerned in the production of epidemics and pandemics, but of these the resistance or susceptibility of a population to infection must be highly important. The passage of an epidemic leaves behind the more resistant of the population; some do not contract the disease because they are resistant from the outset; others contract the disease, recover, and are probably immune for a time. Repeated epidemics of one type should result in a resistant stock. If the human population has been repeatedly and frequently exposed to infection by this particular influenza virus, it is not easy to understand how a pandemic due to the same virus can occur'.

Laidlaw (1935) synthetized Koen's (1919) view regarding the origin of swine influenza, with information on antigenic dissimilarities between swine and human influenza strains, and differences in the age distribution of antibodies to these viruses in human sera (Andrewes et al., 1935), to formulate a provocative hypothesis: 'It seems to me, indeed, exceedingly probable that the virus of swine influenza is really the virus of the great pandemic of 1918 adapted to the pig and persisting in that species ever since. . . . If our conclusion is justified, it would mean that the virus of the 1918 pandemic, though closely allied to that now current in the human population was really slightly different. The very difference between the two strains of virus gives us a possible explanation for the pandemic. At some time or place a variant of the current influenza virus appeared and this variant might be expected to flourish in a population which was resistant to the parent strain. It is not quite the same thing as a new virus attacking a fully susceptible population, but if the variation were great enough the result as to spread and attack rate might approximate to this and the resulting epidemic might become world wide. Similar arguments might be made for other pandemics, and it is quite possible that all pandemics may be due to the occurrence of variants of one type of original virus'. Laidlaw (1935) labelled these thoughts as 'highly speculative but plausible'. In fact, they were highly prophetic.

In 1936, Pandora's box of antigenic variants was really opened by Magill and Francis (1936). They found that the PR8 and Philadelphia strains which seemed antigenically identical when examined with hyperimmune horse or convalescent ferret sera, could be readily distinguished if use were made of relatively strain-specific rabbit sera, obtained after a single intraperitoneal injection of virus. A rash of papers on antigenic analysis of the currently available strains soon followed. The phenomenon of antigenic variation of human strains was quickly confirmed by Burnet (1937) and by Andrewes (1937). StuartHarris was right in the thick of it, as his report to the Medical Research Council attests (StuartHarris et al., 1938). Because studies on the feasibility of vaccination of humans against influenza were being conducted concurrently, it is not surprising that the early reports on examination of a battery of strains by cross-protection tests referred to their significance for prophylactic immunization. Francis and Magill (1938) wrote 'Since all strains tend to create an extensive zone of immunity when repeatedly inoculated, it may be that numerous inoculations of a potent strain will suffice for protection unless strains differing sharply from those heretofore isolated should be encountered. As an alternative, vaccination with a group of strains embracing the antigenic variation so far detected meets the theoretical needs'.

In an accompanying paper, Smith and Andrewes (1938) noted that the use of a 'non-specific master strain might be expected to have more chances of success because it would evoke an immunologic response of wider range'. Less enthusiasm was expressed for employment of polyvalent preparations owing to the dilution of particularly important components. Obviously, concern about strain composition of influenza vaccine is not a recent development.

Almost in parallel, experience with use of influenza vaccines in man was accumulating rapidly. Francis and Magill (1935b) described cultivation of influenza virus in minced embryo tissue culture and in 1936 gave a preliminary report on vaccination of human subjects with active tissue culture virus (Francis and Magill, 1936). A more detailed report followed 
(Francis and Magill, 1937). Volunteers were screened to ensure that their pre-vaccination sera possessed the least protective power against a $10 \%$ suspension of mouse-adapted virus. At weekly intervals, 11 individuals received subcutaneously 3 doses of culture virus contained in $0.5 \mathrm{~cm}^{3}, 1.0 \mathrm{~cm}^{3}$ and $1.0 \mathrm{~cm}^{3}$ respectively. Two to 3 weeks later, an additional dose of $2.0 \mathrm{~cm}^{3}$ was given by the same route. A second group of 5 subjects received subcutaneously weekly doses of $1.0 \mathrm{~cm}^{3}, 1.0 \mathrm{~cm}^{3}$ and $2.0 \mathrm{~cm}^{3}$. A third group of 7 subjects was inoculated intradermally with 3 weekly doses of $0.5 \mathrm{~cm}^{3}$ of culture virus. Samples of blood were obtained at each vaccination and 10 days after the last. Obviously, questions on optimal dose, route, and schedule were being probed.

The findings were encouraging. Vaccination uniformly increased the capacity of sera to neutralize human influenza virus, as judged by mouseprotection tests. The rise in antibodies occurred abruptly in the second week and was maintained for 2 months. At 5 months a modest decline in antibody was noted. Levels attained after vaccination were comparable to those found after natural infection. The results in the group of individuals receiving vaccine intradermally appeared to follow the same course as in those inoculated subcutaneously, though at a lower level. The vaccine was well tolerated. Fever was not encountered. Local reactions after subcutaneous inoculation were cited as inconstant and extremely mild. Intradermal administration produced more erythema.

At the same time, Stokes et al. (1937) were also testing live influenza vaccines. They used Berkefeld filtrates of $10 \%$ suspensions of infected lungs. One hundred and thirty-eight males from various institutions were vaccinated intramuscularly with swine virus, 110 subjects received the PR8 strain. A large group of non-inoculated controls was identified. The results are difficult to evaluate. Only $31 \%$ of the PR8 vaccinated subjects exhibited a serum neutralizing antibody increase. Vaccination was started after influenza had first become epidemic in the area. It was later shown that 1936 was a period of influenza B prevalence in the United States (Francis, 1940a). Nevertheless, some serological evidence for local type A involvement was presented in the account and the incidence of afebrile respiratory disease was apparently unaffected by vaccination. The attack rate of febrile respiratory disease was reported as $2.7 \%$ in PR8 vaccinees, $12.4 \%$ in S-15 vaccinees and $12.5 \%$ in controls.

An expanded study was carried out by Stokes et al. in 1937 using active chick embryo tissue culture vaccine (Stokes et al., 1937). Before the expected epidemic season, approximately one-third of the residents in 6 institutions received 3 weekly doses of PR8 vaccine intramuscularly. Type A virus was recovered during the ensuing outbreak and a varying reduction of febrile illness ranging from onethird to three-fifths that of the controls was reported. This experience was more convincing.

During the same period, a somewhat more elegant approach was being developed at Mill Hill. Andrewes and Smith (1937) described protection of mice given vaccine prepared as formalin-inactivated filtered $5 \%$ mouse lung suspensions of high titre, and demonstrated antibody increase in a small number of volunteers receiving inactivated vaccines. Stuart-Harris et al. (1938) attempted a controlled field trial in the winter of 1937-38 using formalininactivated filtered $5 \%$ infected mouse lung suspensions administered subcutaneously. Influenza occurred before the schedule of vaccination was completed and the incidence of febrile respiratory disease was low. During the next influenza epidemic, Stuart-Harris, Smith and Andrewes (1940) tested a monovalent vaccine containing the WS strain and a mixed vaccine containing equal parts of WS and PR8. The method of vaccine preparation was the same as that used previously. Specific disease occurred but the incidence of influenza was again too low to afford a valid test. The conclusion was 'it may therefore be unfair to dismiss the formalinized vaccine as useless on the evidence of the 1939 test'. Nevertheless, the failure to confirm vaccine efficacy was sobering.

During the next 2 years, field trials of inactivated vaccines continued to yield inconsistent results. A beneficial effect was described in 2 studies (Horsfall et al., 1941; Brown et al., 1941); no benefi ${ }_{t}$ was noted in 3 others (Taylor and Dregus, 1940. Dalldorf, Whitney and Ruskin, 1941; Siegel et al.' 1942a, b). Possible explanations for certain of the' inconsistencies were suggested in a later review (Francis, 1950).

Concurrent with the vaccine studies were those designed to disclose the pathogenesis of influenza and the mechanism of vaccine effectiveness. Many of these have already been cited. Francis and StuartHarris published in 1938 a fundamental set of 3 papers entitled 'Studies on the nasal histology of epidemic influenza virus infection in the ferret'. The first, 'The development and repair of the nasal lesion', extended the initial observations of Smith et al. (1933). Total rapid destruction of the respiratory epithelium with evolution of total repair through stages of transitional and squamous to the final stratified columnar epithelium was described in detail (Francis and Stuart-Harris, 1938a). In the second, 'The resistance of regenerating respiratory epithelium to reinfection and to physiochemical injury', the immature transitional type of epithelium which covers the respiratory area on the seventh or 
eighth day after infection, was shown to be resistant to reinfection with influenza virus and to severe physiochemical injury (Stuart-Harris and Francis, 1938). The third, 'Histologic and serologic observations on ferrets receiving repeated inoculations of epidemic influenza virus', called attention to the role of serum antibody in limiting the extent of cellular injury and the existence of an exaggerated reparative capacity in the virus-conditioned animal. The degree of immunity found in reinfection was considered the product of serological immunity and the rate of tissue repair (Francis and Stuart-Harris, 1938b).

Obviously, cellular as well as humoral factors were involved; yet more information was needed. Discrepancies between levels of serum antibody found in certain individuals and their resistance to natural infection had been noted in a number of the early publications. The results of studies on the relation between serum antibody and the clinical and histological responses of challenged ferrets also made it clear that circulating antibodies did not fully control susceptibility of the upper respiratory tract. Francis (1940b) focused attention upon the significance of local humoral factors. Nasal secretions of a high proportion of human subjects were shown to contain neutralizing antibodies, and the concentration of these, while low or undetectable in acute specimens, was found to be substantially increased following an attack of influenza. Intercurrent attacks of the 'common cold' had no such effect (Francis and Brightman, 1941). Of primary importance to the question of prevention of influenza by vaccination was the demonstration by Francis et al. (1943) that subcutaneous administration of active or inactive virus was followed promptly by a substantial increase in nasal as well as serum antibody. A model for natural or vaccine induced resistance to influenza could now be discerned. Cellular and humoral factors conditioned by prior antigenic experience conferred the primary defence at the portal of entry. Serum antibody, available to respiratory membranes by transudation, constituted an important secondary resource that limited the extent of injury.

At that time then, there was a model of how influenza vaccines could or should work, but no explanation of why they did not, at least consistently. Because of the overall correlation found between levels of serum antibody and resistance to disease (Hoyle and Fairbrother, 1937), one possible explanation for the failures was that they were the consequence of employment of weak vaccines incapable of stimulating antibody levels to uniformly adequate heights. In short order, a series of technical developments made it possible to test this hypothesis. Some time before, Smith (1935) and, in- dependently, Burnet (1935) had described cultivation of influenza viruses on the chorio-allantoic membrane.

In 1940, Burnet reported that large quantities of virus appeared in allantoic fluids from embryos inoculated amniotically. In 1941, Henle and Chambers described the high concentration of influenza $A$ virus and the low protein content of allantoic fluids harvested after intra-allantoic inoculation. In the same year, Burnet (1941) showed that 48-hr allantoic fluid yields of type $A$ and $B$ viruses possessed excellent immunizing capacity when injected into mice subcutaneously.

The discovery of viral haemagglutination in 1941 by Hirst and independently by McClelland and Hare (1941) greatly accelerated the pace of research on influenza. It was now possible to measure virus antibody concentration rapidly, reliably and cheaply. Hirst and his colleagues (Hirst, 1942; Hirst et al., 1942) showed by the use of active allantoic fluid virus and centrifuged concentrates that the haemagglutination inhibiting antibody response of human subjects was increased as the dose of subcutaneous vaccine was increased. In a later study, Hirst, Richard and Whitman (1942) found that the results obtained with formalin-inactivated vaccine were as good as or better than those attained with active preparations. Clearly the stage was now set to initiate definite studies on the benefits of vaccination against influenza. The Commission on Influenza of the Armed Forces Epidemiological Board was founded in 1941 in response to concern about the threat of epidemic influenza as an accompaniment of global warfare. Its early history and some of the early difficulties have been reviewed elsewhere (Francis, 1958; Davenport, Lennette and Meiklejohn, 1970). No one in the United States other than Dr Thomas Francis Jr had the stature or possessed the persuasive, administrative, and scientific skills needed to assemble and direct such a prestigious group of colleagues. One of the first tasks was to obtain supplies of concentrated inactivated vaccine, since unconcentrated formalin-inactivated allantoic fluid samples submitted by 5 different firms proved to be irregularly immunogenic. Concentration by collection of precipitates formed by cycles of freezing and thawing was tried, but this method was unsuitable for mass production. Francis and Salk (1942), pursuing a suggestion of McClelland and Hare (1941) described 10-fold concentration of allantoic fluid virus by adsorption and elution from the infected chick embryo's own erythrocytes. Fortunately, the preparation of eluate vaccine proved feasible. Standards were set after tedious exploration on concentration of formalin, of bacteriostatic agents, and of stability under various storage conditions. Members of the Commission 
visited production units to transport materials, instruct in basic techniques and consult on production problems. Capability for influenza vaccine production was not pre-existent, but had to be created.

A field trial of the standardized product was attempted in 1942, but contrary to anticipation, epidemic influenza did not occur. However, volunteer studies were carried out after the expected epidemic period had passed. Some protection against induced influenza $\mathbf{A}$ and $\mathbf{B}$ was reported (Francis et al., 1945; Salk et al., 1945). These, and the results of an earlier study by Henle, Henle and Stokes (1943), encouraged hope that concentrated inactivated vaccines would prove effective against natural challenge. The fact that they are is now well established. The outcome of 14 carefully controlled field trials conducted over a 30-year period by members of the Commission on Influenza is an important part of the record (Francis, 1953; Francis and Maassab, 1965a; Davenport, 1973). Only a selected portion of this component of the search for an ideal vaccine will be cited.

In May of 1943, the Weiss strain of influenza A was isolated from a sporadic case in Michigan. It appeared antigenically remote from PR8 and because it was reasoned that the next outbreak might be caused by strains of similar antigenic composition, the 1943 isolate was added to the test vaccine. It was not possible to partition the high degree of protection observed in the 1943 trials between the 2 type $A$ virus vaccine components and the question whether antigenic differences of this magnitude play a significant role in vaccine effectiveness remained unanswered (Taylor and Dregus, 1940). In 1945, the same vaccine conferred an even more substantial degree of protection against influenza B. Since the 1945 epidemic type B strains exhibited sharp serological differences from the Lee vaccine component, one might have concluded at this point that the consequences of antigenic variation for vaccine-induced protection had been overestimated. Possibly, the key factor was the amount of virus given. The strain composition of vaccine adopted by the military for control of influenza and employed by the Commission on Influenza in further field tests remained unchanged.

However, the events of 1947 brought about reappraisal. Vaccination with $\mathrm{H}_{0} \mathrm{~N}_{1}$ strains did not prevent $\mathbf{H}_{1} \mathrm{~N}_{1}$ infection. Clearly antigenic variation was of importance to immunity, yet this experience did not disclose the degree to which serological disparity between vaccine and epidemic strains could extend without jeopardizing vaccine effectiveness. Eventually, a pragmatic answer came from the field studies. The questions in 1947 were: could $\mathrm{H}_{1} \mathrm{~N}_{1}$ vaccines be developed? Would they induce sub- stantial levels of $\mathrm{H}_{1} \mathrm{~N}_{1}$ antibodies, and if so would vaccine-induced protection result? These questions were not easy to answer. Attempts at mass production of vaccine containing the newly isolated $\mathrm{H}_{1} \mathrm{~N}_{1}$ strains were hampered initially by poor yields in eggs and greater sensitivity to degradation by formalin. Eventually, these difficulties were overcome and potent vaccines became available. The $\mathrm{FM}_{1}$ strain of 1947 did induce in vaccinees levels of homologous antibody comparable to those found in convalescents. In field trials $\mathbf{F M}_{1}$ vaccine was shown to be protective in 1948 and again in 1950. Because antigenic variation amongst $\mathrm{H}_{1} \mathrm{~N}_{1}$ isolates continued to occur during 1957, efforts were made to ascertain whether vaccine-induced protection could be enhanced if the strains injected as vaccines were closely coupled in time to those encountered in epidemics. The answer seemed to be that 'vaccine vintage' was a relatively unimportant factor (Davenport, 1967). The important consideration was whether the product used induced substantial levels of serum HI antibodies detectable with the epidemic strain. If that condition were met, the year of isolation of vaccine virus seemed irrelevant. This simple correlation has served as a useful guide for decisions that had to be made when, in turn, $\mathrm{H}_{2} \mathrm{~N}_{2}$, $\mathrm{H}_{3} \mathrm{~N}_{2}$ and $\mathrm{H}_{1} \mathrm{~N}_{1}$ viruses re-emerged in 1957, 1968, and 1978 respectively. Vaccination against Asian and Hong Kong influenza proved to be just as successful as against their predecessors. Parenthetically, one would predict that vaccination against the Russian 1977 virus will pose no special problems. It is said to resemble the FW150 strain quite closely, and prevention of what used to be called 'influenza A prime' by the use of FW150 vaccine was established by the Commission's studies in the early 1950s.

Acceptance of the protective value of influenza virus vaccines has been greatly facilitated by the results of a second continuous set of studies carried out under the auspices of the MRC Influenza Vaccine Committee. Not only did this information provide independent validation of the safety and benefit of vaccination, but it extended the scope of the studies as well. Observations were made in open as well as closed populations, in persons of widely different ages, different states of health, different occupations and different conditions of residence. Some data on duration of protection and on effects of repeated vaccination were recorded. Details of the findings are given elsewhere (StuartHarris and Schild, 1976a). The overall conclusion was that a potent, properly constituted vaccine provides an important degree of protection against epidemic and pandemic influenza. Sir Charles Stuart-Harris played a central role in the development, conduct and analysis of the MRC studies 
analogous to that of Dr Francis in the American effort.

Aside from benefit, brief mention should be made of several other aspects of the search for an ideal influenza virus vaccine. A repetitive theme has been antigen concentration; how to achieve it and how to measure it. The early eluate vaccines were soon replaced by ones prepared by Sharples centrifugation. Both were relatively crude products. Since the late 1960s, use of the zonal centrifuge has proviæed highly refined preparations. They are somewhat less irritating locally, but systemic reactions are encountered when high doses are administered, especially in childhood. Measurement remains somewhat of a problem. For more than 3 decades, Miller and Stanley's (1944) CCA (chick cell agglutination) test has been the procedure employed in the United States for assay of virus content of commercial vaccines. It has proved to be a useful test when carefully performed and monitored (Tauraso, O'Brien and Seligman, 1969).

However, because viral aggregates, viral filaments and viral fragments may react with erythrocytes as if each were a single virus particle, CCA titres can be unreliable indices of antigen mass, depending upon the mixture tested. It is hoped that an improved single-radial-immunodiffusion technique devised by Wood et al. (1977) will circumvent these difficulties and permit quantitative estimates of antigen content of vaccines on a gravimetric scale. Ideally, vaccine release should be based on proof of antigenic potency, not on validation of antigen mass. However, animal potency test results exhibit unacceptable variability and cannot be relied upon as predictors of performance in man (Tauraso et al., 1969).

Questions on the optimal route of administration are by this time fairly well resolved. The larger dose that can be administered subcutaneously generally performs as a stronger stimulus than does the smaller, intradermal one commonly used (Davenport and Hennessy, 1960). Appleby, Himmelweit and Stuart-Harris (1951) contributed important data to this point. The application of intranasal sprays containing large amounts of inactivated viruses has not proved as beneficial as the routine use of vaccine subcutaneously when evaluated in field trials (Waldman et al., 1969) or in volunteer studies (Beare et al., 1969). Questions on the optimal dose and schedule to be employed for vaccination are recurrent ones. The goal is to obtain high levels of antibody orientated to the prevailing virus as cheaply as possible, while avoiding vaccine reactions. Height of antibody level is deemed desirable as a counterpoise to antigenic drift. The advantages of economy are obvious. Above a critical dose level, further increments in antibody response are minimal. Below a certain level, antibody formation is puny, especially on primary stimulation. Systemic reaction rates are clearly dose-dependent. Children are much more sensitive than adults. While the occurrence of febrile reactions has largely been eliminated even in childhood by use of ether (Davenport et al., 1961), desoxycholate (Webster and Laver, 1966) or tri (N-butyl) phosphate (Ruben and Jackson, 1972) disrupted virus vaccines, such preparations are not entirely innocuous for infants. The ultimate dose arrived at is a compromise dictated by considerations of tolerance and economy in relation to levels of antibody desired at different ages. These aspects have been thoroughly reviewed in the monograph recently published by Stuart-Harris and Schild (1976b).

Administrative convenience remains the primary reason for recommending a single dose schedule, except in the case of children where use of multiple small doses is advised to compensate for their relative intolerance. However, it has been known since 1956 that differences in the antigenic experience of several age cohorts of the population largely determine the vigour of their antibody response to distinct sets of the antigens of influenza $\mathrm{A}$ viruses. A vaccine of high viral content is a weak stimulator of homologous antibodies in subjects of any age who are undergoing primary experience with those particular antigens by that vaccination. Furthermore, because of the persistent antibody-orientating effects of childhood infection, the antigenically more experienced cohorts produce maximal amounts of heterologous antibodies while the homologous vaccine antibody response is dampened (Davenport and Hennessy, 1956). A single dose of vaccine functions efficiently only when given to individuals primed to respond to it in a booster fashion.

Fortunately, lack of antigenic experience and the dominant effects of past exposures can be largely overcome at all ages by use of an appropriate 2dose schedule (Davenport and Hennessy, 1957). An interval of at least one month is required for adequate priming. That information was exploited in the U.S.A. when Asian influenza threatened. The recommendation was to use 2 doses given at least one month apart. The necessity of employing a properly spaced 2-dose schedule for successful vaccination of unprimed subjects was again demonstrated in the course of studies on swine influenza vaccine carried out in the United States by Parkman et al. (1976). Such a schedule will probably be needed now for immunization of persons 25 years of age or less against A/Russian/77-like viruses. Knowledge of current antibody profiles by age and of responses of different cohorts to prior influenza virus vaccines can generally provide a reliable basis for decisions concerning when and where 2-dose schedules should be employed. Alternatively, antigenicity 
studies can be carried out in man before adoption of recommendations if time permits. Such trials are expensive.

Unfortunately, the use of adjuvants does not eliminate the need of 2 doses for effective vaccination of the antigenically inexperienced or overexperienced, although the amount of antigen required can be greatly reduced thereby (Hennessy and Davenport, 1961).

Aside from conservation of antigen, other advantages conferred by adjuvants, especially by the water in mineral oil type, are enhanced height and duration of elevated antibody levels, thus eliminating the requirement for annual boosters. This unfinished chapter in the search for an ideal influenza vaccine was extensively reviewed by Sir Charles StuartHarris (1969).

Formerly, arguments about strain composition of influenza virus vaccines were more violent than they are now. The desire to substitute the most recent isolate for an earlier one, in the hope that by doing so one could foster antigenic closeness to the next variant, had to be checked with the realization that new isolates generally grow poorly in eggs and may be more sensitive to a host of deleterious conditions including exposure to formalin. These difficulties are currently being overcome by the use of genetic reassortment techniques, first adapted to vaccine production by Kilbourne (1969). The surface antigens of recent epidemic strains can be rapidly substituted for those of stable high yield, older, eggadapted viruses, such as PR8, providing thereby a more effective vaccine seed stock.

Polyvalent vaccines were in general use in the United States for the decade preceding 1968. The thesis was developed in Ann Arbor that the number of antigens of influenza virus was finite, that the antigens of strains formerly prevalent would be recycled, and that the ideal vaccine would be one of broad coverage capable of inducing at all ages a composite of antibodies like that characteristic of the older segments of the population whose resistance is at all times the highest, irrespective of the antigenic characteristics of the prevailing virus (Francis, 1952; Davenport and Hennessy, 1957). While there no longer can be any doubt that recycling does occur, experience has shown that the number of sub-types of influenza A virus is so great that one cannot with aqueous products achieve adequate antibody coverage against all. Incorporation of the older strains dilutes the amount of contemporaneously relevant antigens that can be given. Until acceptable adjuvants become available, the further use of truly polyvalent vaccines is impracticable.

Finally, another approach to prevention is the improvement of live influenza virus vaccines. Essentially this is an area of product development rather than one of discovery of new principles. Vast experience in the U.S.S.R. has shown that live influenza vaccines are safe, generally well tolerated when used as recommended, and about as effective as killed vaccines (Francis and Maassab, 1965b). Whether their performance can be enhanced by the application of the sophisticated techniques now available for selection and testing of candidate vaccine strains remains to be determined. These aspects have been extensively reviewed by Beare (1975) and by Murphy, Spring and Channock (1976).

It is surely evident to all that, despite enormous progress along a difficult road, we do not yet have the ideal influenza vaccine. We only have very effective ones that are being under-utilized at present (StuartHarris, 1970). Nevertheless, it should be noted that the beginnings were brilliant, the coursing has been courageous and, whilst the present seems imperfect, the future fascinates because of the remaining challenges. Sir Charles Stuart-Harris has been and is certain to continue to be a prime mover in the ultimate search for the ideal influenza vaccine.

\section{References}

ANDREWES, C.H. (1937) Influenza: four years' progress. British Medical Journal, 2, 513.

ANDREWES, C.H., LAIDlaW, P.P. \& SMITH, W. (1934) Susceptibility of mice to viruses of human and swine influenza. Lancet, ii, 859.

Andrewes, C.H., Laidlaw, P.P. \& Smith, W. (1935) Influenza: observations on the recovery of virus from man and on the antibody content of human sera. British Journal of Experimental Pathology, 16, 566.

ANDREWES, C.H. \& SMrTh, W. (1937) Influenza: further experiments on the active immunization of mice. British Journal of Experimental Pathology, 18, 43.

ApPleby, J.C., Himmelweit, F. \& Stuart-Harris, C.H. (1951) Immunization with influenza virus $A$ vaccines: comparison of intradermal and subcutaneous routes. Lancet, i, 1384.

Beare, A.S. (1975) Live viruses for immunization against influenza. In: Progress in Medical Virology (Ed. by J. L. Melnick), vol. 20, pp. 49-77. Karger, Basel.

Beare, A.S., Hobson, D., Reed, S.E. \& TYrrell, D.A.J. (1969) Antibody responses to and efficacy of an inactivated spray vaccine. Bulletin of the World Health Organization, 41, 549.

Brown, J.W., Eaton, M.D., Meiklejohn, G., Lagon, J.B. \& Kerr, W.J. (1941) An epidemic of influenza. Results of prophylactic inoculation of a complex influenza Adistemper vaccine. Journal of Clinical Investigation, 20, 663.

BuRnet, F.M. (1935) Propagation of the virus of epidemic influenza on the developing egg. Medical Journal of Australia, 2, 687.

BURNET, F.M. (1937) Influenza virus of the developing egg. I. Differentiation of two antigenic types of human influenza virus. Australian Journal of Experimental Biology and Medical Science, 15, 369.

BURNET, F.M. (1940) Influenza virus infections of the chick embryo by the amniotic route. I. General character of the infections. Australian Journal of Experimental Biology and Medical Science, 18, 353. 
Burnet, F.M. (1941) Growth of influenza virus in the allantoic cavity of the chick embryo. Australian Journal of Experimental Biology and Medical Science, 19, 291.

Dalldorf, C., Whitney, E. \& Ruskin, A. (1941) Controlled clinical test of influenza A vaccine. Journal of the American Medical Association, 116, 2574.

DAVENPORT, F.M. (1967) Present status of inactivated influenza virus vaccines. First International Conference on Vaccines Against Viral and Rickettsial Diseases of Man. Scientific Publication of the Pan American Health Organization, 147, 3 .

DAVENPORT, F.M. (1973) Control of influenza. Medical Journal of Australia (Sp. Suppl.), 1, 33.

Davenport, F.M. \& Hennessy, A.V. (1956) A serologic recapitulation of past experiences with influenza A: antibody response to monovalent vaccine. Journal of Experimental Medicine, 104, 85.

Davenport, F.M. \& Hennessy, A.V. (1957) Predetermination by infection and by vaccination of antibody response to influenza virus vaccines. Journal of Experimental Medicine, 106, 835.

Davenport, F.M. \& Hennessy, A.V. (1960) Prevention of influenza in childhood by vaccination: principles, problems and progress. In: Viral Infections of Infancy and Childhood (Ed. by Rose, H.M.) pp. 152-155. Hoeber-Harper, New York.

DaVenport, F.M., Hennessy, A.V., Brandon, F.M., Webster, R.G., Barrett JR, C.D. \& Lease, G.O. (1961) Comparisons of serologic and febrile responses in humans to vaccination with influenza $\mathbf{A}$ viruses or their hemagglutinins. Journal of Laboratory and Clinical Medicine, 63, 5.

Davenport, F.M., Lennette, E.H. \& Meiklejohn, G.N. (1970) Origins and development of the Commission on Influenza. Archives of Environmental Health, 21, 267.

Francis JR, T. (1934a) The development of the 1943 vaccination study of the Commission on Influenza. American Journal of Hygiene, 42, 1.

Francis JR, T. (1934b) Transmission of influenza by a filterable virus. Science. New York, etc., 80, 457.

FRANCIS JR, T. (1935) Immunologic relationships of strains of filterable virus recovered from cases of human influenza. Proceedings of the Society for Experimental Biology and Medicine, 32, 1172.

FRANCIS $J_{R}, T$. (1940a) A new type of virus from epidemic influenza. Science. New York, etc., 92, 405.

Francis JR, T. (1940b) The inactivation of epidemic influenza virus by nasal secretions of human individuals. Science. New York, etc., 91, 108.

FraNCIS $J_{R}, T$. (1950) Immunity and vaccination in influenza. In: Handbuch der Virusforschung (Ed. by Doerr, R. and Hallauer, C.), vol. 3, pp. 71-73. Springer Verlag, Vienna.

FRANCIS JR, T. (1952) Significance of antigenic variation of influenza viruses in relation to vaccination in man. Federation Proceedings, 11, 808.

Francis JR, T. (1953) Vaccination against influenza. Bulletin of the World Health Organization, 8, 725.

Francis JR, T. \& Brightman, I.J. (1941) Virus-inactivating capacity of nasal secretions in the acute and convalescent stages of influenza. Proceedings of the Society for Experimental Biology and Medicine, 48, 116.

Francis $J_{R}, T$. (1958) Influenza. In: Preventive Medicine in World War II (Ed. by Coates Jr, J.) pp. 85-128. Government Printing Office, Washington, D.C.

Francis JR, T. \& MAASSAB, H.R. (1965a) Influenza viruses. In: Viral and Rickettsial Infections of Man (Ed. by Horsfall Jr, F.L. and Tamm, I), pp. 722-728. Lippincott, Philadelphia.

Francis JR, T. \& MAASSAB, H.F. (1965b) Influenza viruses. In : Viral and Rickettsial Infections of Man (Ed. by Horsfall
Jr, F.L. and Tamm, I.), pp. 728-729. Lippincott, Philadelphia.

Francis JR, T. \& Magill, T.P. (1935a) Immunologic studies with the virus of influenza. Journal of Experimental Medicine, 62, 505.

Fr ANCIS JR, T. \& MAGILl, J.P. (1935b) Cultivation of hi man influenza virus in artificial medium. Science. New Ycrk, etc., 82, 353.

FRANCIS JR, T. \& MAGILL, T.P. (1936) Vaccination of human subjects with virus of human influenza. Proceedings of the Society for Experimental Biology and Medicine, 33, 604.

Francis, JR, T. \& Magill, T.P. (1937) The antibody response of human subjects vaccinated with the virus of human influenza. Journal of Experimental Medicine, 65, 251.

FRANCIS JR, T. \& MAGILL, T.P. (1938) Antigenic difference in strains of epidemic influenza virus: II. Cross immunization tests in mice. British Journal of Experimental Pathology, 19, 284.

Francis Jr, T., Pearson, H.E., Sullivan, E.R. \& Brown, P.N. (1943) The effect of subcutaneous vaccination with influenza virus upon the virus-inactivating capacity of nasal secretions. American Journal of Hygiene, 37, 294.

Francis, JR, T. \& SAlK, J.E. (1942) A simplified procedure for the concentration and purification of influenza virus. Science. New York, etc., 96, 499.

Francis Jr, T., Salk, J.E., Pearson, H.E. \& Brown, P.N. (1945) Protective effect of vaccination against induced influenza A. Journal of Clinical Investigation, 24, 536.

Francis JR, T. \& Stuart-Harris, C.H. (1938a) Studies on the nasal histology of epidemic influenza virus infection in the ferret. I. The development and repair of the nasal lesion. Journal of Experimental Medicine, 68, 789.

Francis JR, T. \& Stuart-Harris, C.H. (1938b) Studies on the nasal histology of epidemic influenza virus infection in the ferret. III. Ferrets receiving repeated inoculations of epidemic influenza virus. Journal of Experimental Medicine, 68, 813.

Henle, W. \& Chambers, L.A. (1941) The serologic activity of extra embryonic fluids of chick infected with virus of influenza A. Proceedings of the Society for Experimental Biology and Medicine, 46, 713.

Henle, W., Henle, G. \& Stokes Jr, J. (1943) Demonstration of the efficiency of vaccination against influenza type A by experimental infection of human beings. Journal of Immunology, 46, 163.

Hennessy, A.V. \& Davenport, F.M. (1961) Relative merits of aqueous and adjuvant influenza vaccines when used in a two-dose schedule. Public Health Reports, 76, 411.

HiRST, G.K. (1941) The agglutination of red cells by allantoic fluid of chick embryos infected with influenza virus. Science, New York, etc., 94, 22.

Hirst, G.K. (1942) The quantitative determination of influenza virus and antibodies by means of red cell agglutination. Journal of Experimental Medicine, 75, 49.

Hirst, G.K., Rickard, E.R. \& Whitman, L. (1942) A new method for concentrating influenza virus from allantoic fluid. Proceedings of the Society for Experimental Biology and Medicine, 50, 129.

Hirst, G.K., Rickard, E.R., Whitman, L. \& Horsfall JR, F.L. (1942) Antibody response of human beings following vaccination with influenza viruses. Journal of Experimental Medicine, 75, 495.

Horsfall JR, F.L., Lennette, E.H., Rickard, E.R. \& HirST, G.K. (1941) Studies on efficacy of complex vaccine against influenza A. Public Health Reports, 56, 1863.

HoYle, L. \& FAIRBrother, R.W. (1937) Isolation of the influenza virus and the relation of antibodies to infection and immunity. British Medical Journal, 1, 655. 
Kilbourne, E.D. (1969) Future influenza vaccines and the use of genetic recombinants. Bulletin of the World Health Organization, 41, 643.

KOEN, J.S. (1919) A practical method for field diagnosis of swine diseases. American Journal of Veterinary Medicine, 14, 468.

Laidlaw, P.P. (1935) Epidemic influenza: a virus disease. Lancet, i, 1118.

Laidlaw, P.P., Smith, W., Andrewes, C.H. \& Dunkin, G.W. (1935) Influenza: the preparation of immune sera in horses. British Journal of Experimental Pathology, 16, 275.

McClelland, L. \& Hare, R. (1941) The adsorption of influenza virus by red cells and a new in vitro method of measuring antibodies for influenza virus. Canadian Public Health Journal, 32, 530.

MaGill, T.P. \& Francis JR, T. (1936) Antigenic differences in strains of human influenza virus. Proceedings of the Society for Experimental Biology and Medicine, 35, 463.

Miller, G.L. \& Stanley, W.M. (1944) Quantitative aspects of the red blood cell agglutination test for influenza virus. Journal of Experimental Medicine, 79, 185.

MurPhy, B.R., SPring, S.B. \& Chanock, R.M. (1976) Live vaccine: production and use. In: Influenza Virus Vaccine Strategy and Use (Ed. by Selby, P.), pp. 179-197. Academic Press, New York.

Parkman, P.D., Galasso, G.J., Top JR, F.H. \& Noble, G.R. (1976) Summary of clinical trials of influenza vaccines. Journal of Infectious Diseases, 134, 100.

Ruben, F.L. \& JaCkson, G.G. (1972) A new subunit influenza vaccine: acceptability compared with standard vaccines and effect of dose on antigenicity. Journal of Infectious Diseases, 125, 656.

Salk, J.E., Pearson, H.E., Brown, P.N. \& Francis JR, T. (1945) Protective effect of vaccination against induced influenza B. Journal of Clinical Investigation, 24, 247.

ShOPE, R.E. (1932) Studies on immunity to swine influenza. Journal of Experimental Medicine, 45, 575.

Siegel, M., Muckenfuss, R.S., Schaeffer, M., Wilcox, H.L. \& Lieder, A.G. (1942a) Studies in active immunization against epidemic influenza and Pneumococcus pneumonia at Letchworth Village. III. The results of active immunization against epidemic influenza from 1927 to 1940. American Journal of Hygiene, 35, 55.

Siegel, M., Muckenfuss, R.S., Schaeffer, M., Wilcox, H.L. \& Lieder, A.G. (1942b) Studies in active immunization against epidemic influenza and Pneumococcus pneumonia at Letchworth Village. IV. Results of an epidemic of influenza A in 1940-41. American Journal of Hygiene, 35, 186.

Smith, W. (1935) Cultivation of the virus of influenza. British Journal of Experimental Pathology, 16, 508.

SMith, W. \& ANDREWes, C.H. (1938) Serologic races of influenza virus. British Journal of Experimental Pathology, 19, 293.

Smith, W., Andrewes, C.H. \& Laidlaw, P.P. (1933) Virus obtained from influenza patients. Lancet, ii, 66.
Smith, W., Andrewes, C.H. \& Laidlaw, P.P. (1935) Influenza: experiments on the immunization of ferrets and mice. British Journal of Experimental Pathology, 16, 291.

Stokes JR, J., Chenoweth, A.D., Waltz, A.D., Gladen, R.D. \& SHAw, D. (1937) Results of immunization by means of active virus of human influenza. Journal of Clinical Investigation, 16, 237.

StUART-HarRis, C.H. (1969) Adjuvant influenza vaccines. Bulletin of the World Health Organization, 41, 617.

Stuart-Harris, C.H. (1970) Control of influenza. Archives of Environmental Health, 21, 276.

Stuart-Harris, C.H., ANDrewes, C.H., Smith, W., Chalmers, P.K.M., Handrewes, E.G. \& Hughes, D.L. (1938) Study of epidemic influenza with the 1936-7 epidemic. Special Report Series of the Medical Research Council. London, No. 228, 108.

Stuart-Harris, C.H. \& Francis JR, T. (1938) Studies on the nasal histology of epidemic influenza virus infections in the ferret. II. The resistance of regenerating respiratory epithelium to reinfection and to physiochemical injury. Journal of Experimental Medicine, 68, 803.

StuART-HARRIS, C.H. \& SCHILD, G.C. (1976a) In: Influenza: The Viruses and the Disease (Ed. by Publishing Sciences Group, Inc.), pp. 175-178. Littleton, Massachusetts.

Stuart-Harris, C.H. \& SCHILd, G.C. (1976b) Immunization with influenza virus vaccines. In: Influenza: The Viruses and the Disease (Ed. by Publishing Sciences Group, Inc.), pp. 166-167. Littleton, Massachusetts.

Stuart-Harris, C.H., Smith, W. \& Andrewes, C.H. (1940) The influenza epidemic of January-March, 1939. Lancet, $\mathbf{i}$, 205.

Tauraso, N.M., O'Brien, T.C. \& Seligman Jr, E.B. (1969 Problems of influenza virus vaccine standardization Bulletin of the World Health Organization, 41, 497.

TAYLOR, R.M. \& DREgUS, M. (1940) An experiment in immunization against influenza with formaldehydeinactivated virus. American Journal of Hygiene, 31, 31.

TheILER, M. \& SMITH, H.H. (1937) Use of yellow fever virus modified by in vitro cultivation for human immunization. Journal of Experimental Medicine, 65, 787.

Waldman, R.H., Bond, J.O., LeVITT, L.P., HaRTwig, E.C., Prather, E.C., Barata, R.L., Neill, J.S. \& Small JR, P.A. (1969) An evaluation of influenza immunization. Influence of route of administration and vaccine strain. Bulletin of the World Health Organization, 41, 543.

Webster, R.G. \& LAVER, W.G. (1966) Influenza virus subunit vaccines: immunogenicity and lack of toxicity for rabbits of ether and detergent-disrupted virus. Journal of Immunology, 96, 596.

Wood, J.M., Schild, G.C., Newman, R.W. \& Seagroat, V. (1977) An improved single-radial-immunodiffusion technique for the assay of influenza haemagglutinin: application for potency determinations of inactivated whole virus and subunit vaccines. Journal of Biological Standardization, 5, 237. 